Acuity 4(1), 59-65

\title{
Agnes Grey's Search for Self-Identity in Agnes Grey by Anne Bronte
}

\author{
Yanti Rahayuningsih \\ uts@ypps.uts.ac.id \\ Universitas Teknologi Surabaya
}

\begin{abstract}
This study aims to reveal, identify and describe Agnes Grey's search for self-identity. Also, the writer of the thesis wants to show that the situations in Agnes Grey's adolescence period are the same as the real life of the author, Anne Bronte. The research method used is the psychology of literature. The results of the analysis indicated that by using theory from Erik H. Erikson, Agnes Grey found her true self in three stages.
\end{abstract}

Key Words: self-identity, individuation, psychology approach.

\section{Introduction}

As a human being, it is considered a necessity for us in having a self-identity. Through it, we will finally "understand" who we really are and in the end, we will be able to decide and drive our purpose in life. Besides, if we already have an identity within our self, we would not be confused about living our life in society. The term of searching for self-identity is an important subject considering the situations that could happen.

Self-identity itself is one's concept and images of his/her self. It is "an individual's view of himself consisting of attitudes, feelings, beliefs, perceptions, and behaviors which are uniquely his. ." (Monthe, 422). Self-identity also described as an honest and complete judgment one has for himself (Alwisol, 81).

From the description above, we know that a self-identity is not something that we get since we were born. Self-identity is something we need to find out as the time goes by from many ways in our entire life, for example, we can find it through society which has interacted with us. Through it, we will finally find our own identity, and with the identity in our self, we will be ready in facing the rest of our life.

Jary and Jary pointed out a different view of identity. According to them, the concept of identity has been defined as 'A sense of self that develops as the child differentiates from parents and family and takes a place in society' (1991). Here, we can see that a child's identity is not always the same with the identity of their parents or family's. This situation is shown in the novel Agnes Grey, where the main character, Agnes Grey, finally decides to search for her own living, different from what her parents already had.

Yet, an identity is different with self-awareness since self-identity is not a notion of self. Means that identity is not the same with the understanding of self, but it is a symbol of our self. In psychology, self-identity relates to self-image (a person's mental model of him or herself), self-esteem, and individuation. It dictates to a significant degree how an individual view him or herself both as a person and in relation to other people (known as gender identity). 
Meanwhile, self-esteem is the pride of somebody to him or her own self, whether this pride is a good one or a bad one. On the other hand, individuation means a process within someone's life during their life to found "the real them" so that they will feel complete. Self-esteem or self-worth, the positive feelings of merit and the extent to which the child believes his attributes and actions are good, desired and valued (Hall, 1978).

Further understanding of self-identity could be analyzed through literary works, since it mostly is a reflection of the real situations and conditions of that time and also the picture of readers and even the author him or herself. The easiest way is through analyzing a novel because it can give us a brief description of the situations and conditions itself. A novel itself is a prose story based on the imagination of the author (Roberts, 1969, p. 51).

As I have mentioned above, in this research the writer will analyze a novel by Anne Bronte, Agnes Grey. It is a novel about a young girl named Agnes Grey who fights in searching her self-identity. She must face a lot of obstacles in order to reach her goals. The situations of hers, especially during the adolescent period, are basically the same with the life of the author, Anne Bronte. In fulfilling her needs, Anne Bronte must work as a governess and leave her family behind and look for her goals. By Anne Bronte's novel, we will be able more understand in the idea of searching for self-identity and find out the obstacles that happen during someone's searching for self-identity.

\section{Research Methodology}

This study is using the Psychological Approach. The data will be presented in description analysis. In addition, according Hall, Calvin S. and Gardner Lindsey (1987: 9) idea, which stated that the nature of qualitative data is in the form of words which based on observation, discussion or documents and since the data collected in the form of words rather than numbers, this research uses descriptive qualitative method.

Because this method emphasizes natural and descriptive understanding itself, thus a qualitative research approach is used in this study because the approach is "concerned with the subjective assessment of attitudes, opinions, and behavior." (Alwisol, 2004: 5). It related to the object of this study is novels and the researcher tried to analyze the characters' attitudes, opinions, and behavior in their fiction world.

There are some theories in psychology which are related to the idea of searching for self-identity. Yet, the writer will use one of it, which is Erik H. Erikson's theory, as the main theory in revealing the idea of searching for self-identity. The reason why the writer took that theory is none other because it has the most relationships with the center subject of the research which concentrates on the adolescent period of someone, in this case, Agnes Grey as the main character in the novel. However, other theories that mention identity and their details will also be used to strengthen the analysis.

Erik H. Erikson stated in his book "Identity, Youth and Crisis" that someone, especially the youth, often has some confusion in defining themselves, whether they were born with their parents' identity or they have to decide their own identity which will be used for their entire life. The term "identity confusion" has a certain diagnostic significance which should influence the evaluation and treatment of such disturbances ( $p$. 17).

Erikson also stated that there are some links between pathological and development aspects in dealing with the self-identity itself. The process of differentiation of their life usually begins during the adolescent period of life. During the adolescent period, someone could define their self-identity. The importance of being aware with their self-identity considered as a must for Erikson who believed that establishing a satisfying sense of personal identity and meaningful goals are the single most important challenge of 
adolescence (Psychology: From Research to Applications, 1987, p.68). Furthermore, Erikson has mentioned the three signs that implied the search for self-identity of someone, that are:

1. The first signs mention that if an identity crisis is an important part of the life of someone; therefore, he/she intends to look for someone else to trust to. Here, the adolescence intends to look for someone who could be lived with, yet most of them have some fears of being foolish, with all kinds of commitments which might be happening in the future living and of course, to face those situations without any misunderstanding.

2. The second signs mentioned the necessity of being known by what one can will freely, then the adolescence now looks for an opportunity to decide with free ascent on one of the available or unavoidable avenues of duty and service, and at the same time is mortally afraid of being forced into activities in which he would feel exposed to ridicule or self-doubt. In other words, adolescence intends to search his/her goals in life without any interruptions from others.

3. Last but not least, when the desire to make something work and to make it work well has come up, then the choice of occupation becomes the purpose and the answer to those questions. In this period of life, adolescence intends to look for the most suitable ways in order to fulfill their goals and purposes in life.

\section{Analysis}

\section{Agnes Grey's Search for Self-Identity.}

Erikson has stated in his book that youth often has some confusion in defining themselves, whether they were born with their parents' identity or they have to decide their own identity which will be used for their entire life. They intend to have some eagerness in defining their own self, without any interruption from others, no matter who they are. This situation is well shown in the life of Agnes Grey, where she finally questioning, what her life would become, what will she do in facing her surroundings, and of course, what kind of behaviors she should had, considering she was born as a clergyman's daughter who at that time, has no power to "change" their own faith.

"I am hardly competent to judge. I sometimes think it might prove useful to some, and entertaining to others, but the world may judge for itself. Shielded by my own obscurity, and by the lapse of years and a few fictitious names, I do not fear to venture, and will candidly lay before the public what I would not disclose to the most intimate friend." (Bronte, 1994: 15)

Above, we can see how Agnes Grey's question of life has begun to destruct her thought and mind. She is questioning whether she had the "right" in defining her own goals in life, or should she obey the "rules" which has already been there even when she was not born yet. In the other words, Agnes Grey has already felt confuse in defining her own identity in the eye of her surroundings, and in the end, she thinks that it is a necessity to define her own identity. She feels that her conditions and behaviors should be settled and fixed with the situations of her surroundings in order to have a better life. Yet, this situation becomes much worse when she found out that she has never been taught in reacting to any kind of situations in life.

She felt that what her family has done before is not good enough for her in preparing her own self in entering "the real world". Yet, she never blames them for all trouble she might get, she only regrets it as a carelessness of them who had not taught her about life as brief as they could because she never been taught about the real meaning of life itself, since her family always considered her as "a small child", as mentioned: 
". Though a woman in my own estimation, I was still a child in theirs." (Bronte, 1994: 23)

Her conditions in the family have made her eagerness of the "outside" world arise and finally, it affected her way of thinking to her surroundings.

These situations are describing Eriks on's statement in his book that a young patient can be violent or depressed, delinquent or withdrawn, but theirs are acute and possibly pass crisis rather than a breakdown of the kind which tends to commit a patient to all the malignant implications of a fatalistic diagnosis. From her statement above, we can see that Agnes Grey feels some kind of "regret" since she never feels enough about her present day's activities, as shown: "were the only persons we ever saw". Therefore, she decided to go further, to explore her own capacities in facing life, and of course, in defining her own identity. She thinks that it is necessary to look for the other part of life which she has never been entered before, and so, she decides to try those possibilities; "at least a vague and secret wish to see a little more of the world."

Agnes Grey's questions of life, especially on her own self-identity within society basically made up of two important backgrounds; pathological and development aspect. Means that Agnes Grey's basic interest in the family is none other than she was born as a clergyman's daughter who at that time, has no possible right to "change" those situations, and as time goes by, her sociological development, her relationship with society, is considered not enough since she and her family only have several relatives and never been out of their present town. These conditions finally affected her behavior in facing the reality itself, as stated:

"Under such circumstances, although I was not many degrees more useful than the kitten, my idleness was not entirely without excuse." (Bronte, 1994: 24)

Within her thought, her present conditions are basically affected by the reality of hers that she has no power in changing it, therefore she feels that everything that would happen later are all because of the situations itself.

Here, we could finally see that Agnes Grey has already entered the three stages Erikson ever mention about the signs of someone's searching for self-identity, which are:

\section{Search for trust.}

"The first stage mentions that if an identity crisis is an important part of the life of someone; therefore, he/she intends to look for someone else to trust to" (Identity: Youth and Crisis, 1968, p.129). In this stage, Agnes Grey as the main character begins in questioning her own identity and tries to look for someone else to be trusted to, in this case, is none other than her own family. She always tries to convince her parents and sister that she also has the capabilities and requirements to work as a governess, as well as other people, might become. This situation is shown in some conversations between her herself and her family members.

Despite her family rejection, Agnes Grey insisted to runs her planning to work as a governess for other families. She dealt with this situation by saying the truth and gives a huge trust to the rest of family members, hoping that they would support her decision, yet she does not get that support. However, she keeps trying to ensure them that she is also able to work as a governess no matter what the situations and conditions are;

"Yes, papa, don't you say anything against it: I should like it so much, and I am sure I could manage delightfully." (Bronte, 1994: 27)

Overall, from statements given, we can finally see how Agnes Grey decided to "speak up" and trust the rest of her family members about her plans and eagerness in 
order to answer and figuring out what she has always been searching for, her own selfidentity.

\section{Search for recognition.}

"The second stage mentioned the necessity of being known by what one can will freely, then the adolescent now looks for an opportunity to decide with free ascent on one of the available or unavoidable avenues of duty and service, and at the same time is mortally afraid of being forced into activities in which he would feel exposed to ridicule or self-doubt" (Identity: Youth and Crisis, 1968, p.129). In this stage, adolescent intends to look for his/her own identity and finally, decide the best way for them without any interruptions from others. This adolescent sign can be seen on Agnes Grey's behavior in keeping her plan and willingness to become a governess. She insisted on doing it although the rest of her family members seems to disagree with her. She always sticks on her own thought and picture in becoming a good and reliable governess.

Overall, Agnes Grey's behaviors are a perfect example of how someone could be very persisted in their own thought and mind, and of course, try as hard as they could to make it come true and refuse other possibilities which are shown up in order to prevent his/her own self-doubt. So that, when others give him/her some suggestions-not to reach his/her goals and dreams-adolescent intends to refuse it and decided to search the best way of their own because they think that this is the best for them, as the picture given in Agnes Grey's conditions.

\section{Searching for an occupation.}

"Last but not least, when the desire to make something work and to make it work well has come up, then the choice of occupation becomes the purpose and the answer of those questions" (Identity: Youth and Crisis, 1968, p.129). In this stage, adolescent intends to look for the best way for them in order to make their dream and willingness come true. They have been trying to find the answers of their searching through their occupation. Means that they have been trying to define their selves, who they are and what they are in the eye of society, through their occupation. So that, when someone works as a doctor, means that this someone is considered and known as a doctor, not as an engineer or other types of occupation.

Therefore, the presence of an occupation considered as a must for those who are still searching and questioning his/her own identity. This sign is also happening in Agnes Grey's adolescence period, when she decided to look for an occupation, in this case, she prefers to work as a governess. She finally reaches the stage where the answers of questions that have always been haunting her about her own identity are needed and she chooses to work as a governess as her solution and answer in defining her own identity. Agnes Grey is persisted in making her dream come true, no matter how hard it is. Her struggle finally finds its way when she finally gets the "opening gate" to the dream itself, as shown:

"At last, to my great joy, it was decreed that I should take a charge of the young family of a certain Mrs. Bloomfield, whom my kind, prim Aunt Grey had known in her youth, and asserted to be a very nice woman." (Bronte, 1994: 29)

Overall, we can finally see how the searching for self-identity of Agnes Grey is depicted in the novel. We can see how she finally questioning who and what she really is since she was born as a clergyman's daughter and never been out of her hometown. Although she has to deal with her family's rejection of her being a governess, Agnes Grey 
is still persisted to doing it because she feels that that is the answer of her question, her eagerness in defining who she really was, and surely, what was happen within Agnes Grey's life is a good example of Erik H. Erikson's statement about the idea of searching for self-identity.

\section{Conclusion}

Anne Bronte's Agnes Grey is a story about a young girl name Anne Bronte who was born as a clergyman's daughter and the youngest child in the family. She was born with a huge amount of love and tenderness and was surrounded by people who really care about her. Yet, as the time goes by, she finally decided to search for her own self-identity, to "separate" from her family and looking forward to work as a governess in order to get her own earning, and surely, to define who she really is in the eye of society.

Therefore, in analyzing the idea of searching for self-identity, the writer uses Erik H. Erikson's theory about the idea itself. Erikson has mentioned in his book, Identity: Youth and Crisis, that there are three signs which show the searching for self-identity of someone. These three stages had finally used as a tool for analyzing Agnes Grey's search for self-identity.

The first stages mentioned the importance of looking for someone else's trust. In Agnes Grey's case, she intends to look for her family's trust in order to make her dream come true. She decided to tell them, especially her mother and sister, that she is really eager in working as a governess. She has been wanted for it and persisted to go for her dream although her family disagrees with her decision. She always convinces them that she also has those capabilities that needed in becoming a good governess. At this stage, we can finally see how strong Agnes Grey's desire is, in working as a governess. No matter how hard the rejection from her mother and sister, she still persisted to go for it.

The second stage mentioned that someone who is searching for his/her self-identity is intended to look for other's recognition. In the case of this thesis, we have seen on the previous chapter that Agnes Grey is always trying to look for her family's recognition of her being a governess. Although her families cannot agree with her decision, Agnes Grey is still persisted to work as a governess and keep trying to get her family's recognition and considered as a foolish if she does not work as a governess, therefore, she rejects other's suggestion for her not to work as a governess. Last but not least, the third stages mentioned that those who are searching for self-identity finally decided to look for an occupation which will be used as their identity. It has mentioned before that Agnes Grey intends to work as a governess in defining her identity in the eye of society. Therefore, she tries as hard as she could in searching for a family who would like to hire her and give her an occupation. After a long time waiting and hoping, Agnes Grey finally founds a family who wants her to teach their little children. Although she had worked in the family for quite a long time, she keeps trying to search other family and she successfully got one, with an unusual way, through the newspaper. Overall, here we have finally seen how Agnes Grey's behavior and reaction toward society and surroundings has given us a perfect example of how someone could be very persisted to define their own self-identity.

Overall, through this research, we have seen how the idea of searching for selfidentity of the main character, Agnes Grey, is depicted in the novel, and also, we are shown perfectly of how the adolescence period of Agnes Grey is basically the same with the author's adolescence period, when both of them decided to work as a governess and use it as their identity in the eye of her surroundings.

\section{Bibliography}


Alwisol. 2004. Psikologi Kepribadian. Malang: UMM Press

Barnet, S. \& William E. Cain. 2003. A Short Guide to Writing about Literature. London: Longman Press

Bronte, A. 1994. Agnes Gray. London: Bloomsbury

Erikson, E., H. 1987. Psychology: From Research to Applications. New York: John Wiley \& Sons, Inc

Fudyartanta, R. B. S. 2005. Psikologi Kepribadian Neo Freudianisme. Yogyakarta: Zenith

Frye N. 1952. Anatomy of Criticism: four essays. New Jersey: Princeton University Press

Hall, C., S., \& Gardner Lindsey. 1978. Theories of Personality. New York: John Wiley \& Sons, Inc

Kennedy, X. J. 1985. An Introduction to Fiction, Poetry, and Drama. Third Edition. Boston: Little, Brown Company

Monthe, C., R. 1995. Beneath the Mask: An Introduction to Theories of Personality. Fort Worth: Harcourt Brace College Publisher

Perrine, L. 1983. Literature. Structure, Sound, and Sense. New York: Harcourt, Brace, and World

Withlark, J. An Essay: Stages of the Individuation process. Retrieved on 24 October 2012 from http://www.goertzel.org/dynapsyc/2008/Whitlark.htm 